\title{
A Study of Mobile Phone Addiction and Mental Health among Adolescent Girls Studying in Various Streams
}

\author{
Shaikh Ajhar Shaikh Abdul Wahed Patel ${ }^{1 *}$, Dr. Parmeshwsar Abhiman Puri ${ }^{2}$
}

\section{ABSTRACT}

Present research aims to study mobile phone addiction and mental health among adolescent girls studying in various streams. The study employed survey method of research. Total 150 adolescent girls studying in Arts, Science and Commerce stream of Aurangabad city was selected by Random Sampling method as the sample of the study. Sample consists of 50 adolescent girls from each stream. Tools used for the research were Mobile phone addiction test by Dr.S.Velayudhan \& Dr.S.Srividya and Mental Health Check -list (MHC) by Pramod Kumar .Statistical measures used for data analysis was Mean, SD, and ANNOVA and Pearson's Product Moment Method of Correlation. Results revealed that there is significant difference between the level mobile phone addiction of adolescent girls studying in various streams. No significant difference was found between the level mental health among adolescent girls studying in various streams. Positive and significant correlation was found between mobile phone addiction \& mental health which predicts that higher the level of mobile phone addiction lower will be the mental health. Suggestions were given to reduce mobile phone addiction and improve mental health among adolescent girls.

Keywords: Mobile Phone Addiction, Mental Health, Adolescent Girls.

Worldwide technology and its changes play a major role in each individual's life. The current trend of the society is to adopt every change in the field of communication technology. The mobile phones are boon of this century. Mobile phone is considered as an important communication tool and became the integral part of the society, it is not only a communication device but it also a necessary social accessory. People are increasingly using mobile phones rather than the fixed telephones. A huge chunk of this quantity consists of the youth i.e adolescents. The cell phone is more of a necessity for them than a luxury. Number of surveys conducted on the youth worldwide have figured out that they consider cell phones an integral part of survival and some have even gone to the extent of saying that they would

\footnotetext{
${ }^{1}$ Ph.D Research student, Dept. of Psychology, Dr. Babasaheb Ambadkar Marathwada, University Aurangabad, Maharashtra, India

${ }^{2}$ Assistant Professor, Dept. of Psychology, Government Vidarbha Institute, Science \& Humanities, Amravati, India

*Responding Author

(C) 2017 Patel S A \& Puri P A; licensee IJIP. This is an Open Access Research distributed under the terms of the Creative Commons Attribution License (www.creativecommons.org/licenses/by/2.0), which permits unrestricted use, distribution, and reproduction in any Medium, provided the original work is properly cited.
} 


\section{A Study of Mobile Phone Addiction and Mental Health among Adolescent Girls Studying in Various Streams}

rather go without food for a day than without their cell phones (Vandana Goswami, Dr. Divya Rani Singh, 2016)

Adolescent girls also use mobiles in access and this is nothing but addiction. Mobile phone addiction, sometimes referred to as problematic mobile phone use, is a behavioral addiction thought to be similar to that of an Internet, gambling, shopping, or video game addiction and leads to severe impairment or distress in one's life.

Psychiatrist considered mobile phone addiction to be an Obsessive-Compulsive Disorder (OCD). Mobile phone addiction can totally isolate its victims, ruin them economically and even turn them into criminals. A study shows that overuse of cell phones, especially smartphones, with mental health problems among adolescents. Problems revolving around attention, behaviour and self-regulation are more common among adolescents with high mobile phone usage.

Mental health includes our emotional, psychological, and social well-being. It affects how we think, feel, and act. Mental health is important at every stage of life, from childhood and adolescence through adulthood. The World Health Organization (WHO) defines: health as a state of complete physical, mental and social well-being and not merely the absence of disease or infirmity. The WHO states that "there is no health without mental health. "It affects our ability to make the most of the opportunities that come our way and play a full part amongst our family, workplace, community and friends. In present age, mental disorders are considered as the major and largest problem faced by the society one of the major reason considered is access use of mobile phone among adolescents. Present research is an attempt to study the level of mobile phone addiction and mental health of adolescent girls studying in various stream viz Arts, Science \& Commerce

\section{Objectives}

1. To compare the significant difference between mobile phone of adolescent girls studying in various streams

2. To compare the significant difference between mental health addiction of adolescent girls studying in various streams

3. To study the relationship between mobile phone addiction and mental health among adolescent girls studying in various streams

\section{Hypotheses}

1. There would be significant difference between the between the level of mobile phone addiction of adolescent girls studying in various streams

2. There would be significant difference between the between level of mental health of adolescent girls studying in various streams.

3. There is a positive relationship between mobile phone addiction and mental health of adolescent girls studying in various streams. 


\section{METHODOLOGY}

\section{Sample:}

Total 150 adolescent girls studying in Arts, Science and Commerce stream of Aurangabad city were selected as the sample of the study. Sample consists of 50 adolescent girls from each stream. Sample was selected by Random Sampling method.

\section{Tools:}

Tool used for the research were Mobile phone addiction test by Dr. S. Velayudhan \& Dr. S. Srividya and Mental Health Check -list (MHC) by Pramod Kumar

\section{Statistical Analysis:}

Mean, SD, and ANNOVA and Pearson's Product Moment Method of Correlation test were used to analyze the data.

\section{ANALYSIS AND INTERPRETATION OF DATA}

Hypotheses 1: There would be significant difference between the level of mobile phone addiction of adolescent girls studying in various streams

Table 1.1- Showing the level of mobile phone addiction among adolescent girls studying in various streams

\begin{tabular}{|l|c|c|c|c|}
\hline \multirow{3}{*}{$\begin{array}{l}\text { Mobile phone } \\
\text { addiction }\end{array}$} & Stream & N & Mean & SD \\
\cline { 2 - 5 } & Arts & 50 & 138.56 & 15.867 \\
\cline { 2 - 5 } & science & 50 & 132.12 & 13.859 \\
\cline { 2 - 5 } & commerce & 50 & 139.16 & 15.165 \\
\hline
\end{tabular}

Table no 1.1 reveals that the mean score \& SD for mobile phone addiction of adolescents' girls studying in Arts and commerce stream is $M=138.56$, $S D=15.867 \& M=139.16$ \& $S D=$ 15.165 respectively. On the other hand, mean score \& SD for mobile phone addiction of adolescents' girls studying in science stream is $M=132.12 \& \mathrm{SD}=13$. 859.It was observed that mobile phone addiction among adolescent girls studying in science is less as compared to adolescent girls studying in Arts and Commerce stream. To test whether there are significant differences exists, the data is further subjected to Analysis of variance.

Graph 1.1: Showing the levels of Mobile phone addiction among adolescents girls studying in various streams.

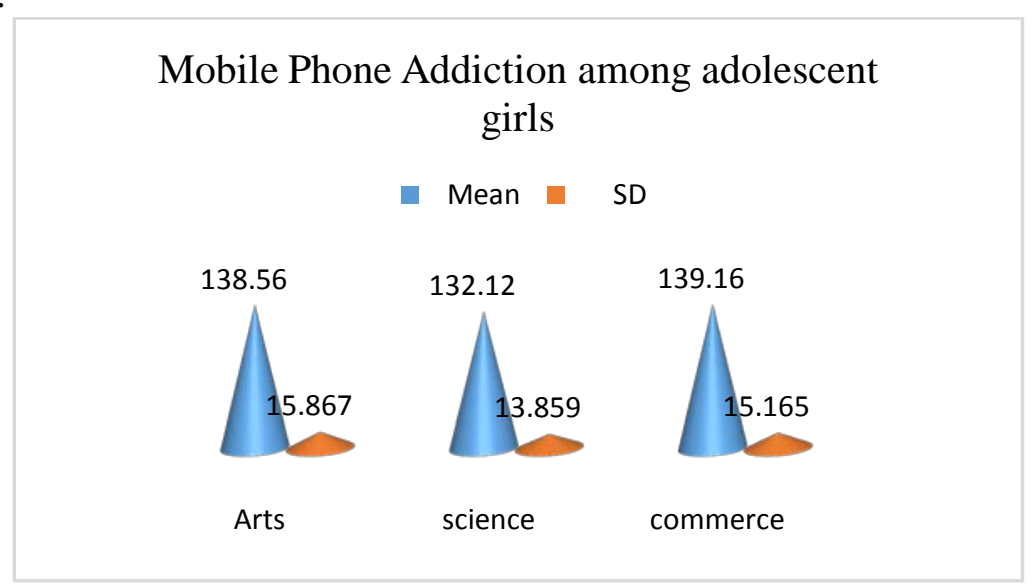

(c) The International Journal of Indian Psychology, ISSN 2348-5396 (e)| ISSN: 2349-3429 (p) | 148 
A Study of Mobile Phone Addiction and Mental Health among Adolescent Girls Studying in Various Streams

Table 1.2- ANNOVA Showing significant difference between the level of mobile phone addiction of adolescent girls studying in various streams.

\begin{tabular}{|l|r|c|c|c|c|}
\hline & Sum of Squares & df & Mean Square & F & Sig. \\
\hline Between Groups & 1523.253 & 2 & 761.627 & & \\
\cline { 1 - 3 } Within Groups & 33016.320 & 147 & 224.601 & \multirow{2}{*}{3.391} & .036 \\
\cline { 1 - 4 } Total & 34539.573 & 149 & & & \\
\hline
\end{tabular}

Table no 1.2 shows that the $F_{(2,147)}$ value for mobile phone addiction is 3.391 which is significant as $\mathrm{p}<0.05(\mathrm{p}=0.036)$. It shows that there is significant difference between the level mobile phone addiction of adolescent girls studying in various streams. The obtained result support stated hypothesis, hence on the basis of result hypothesis is accepted.

Hypotheses 2: There would be significant difference between the level of mental health of addiction of adolescent girls studying in various streams

Table 2.1 - Showing the level of mental health among adolescent girls studying in various Streams.

\begin{tabular}{|l|c|c|c|c|}
\hline \multirow{3}{*}{ Mental health } & Stream & N & Mean & SD \\
\cline { 2 - 5 } & Arts & 50 & 18.24 & 2.932 \\
\cline { 2 - 5 } & science & 50 & 16.78 & 4.478 \\
\cline { 2 - 5 } & commerce & 50 & 18.24 & 3.298 \\
\hline
\end{tabular}

Table no 2 reveals that the mean score \& SD for mental health of adolescents' girls studying in Arts, science \& commerce stream is $\mathrm{M}=18.24, \mathrm{SD}=2.932, \mathrm{M}=16.78$ \& $\mathrm{SD}=4.478$ \& $\mathrm{M}=18.24$ \& $\mathrm{SD}=3.298$ respectively. To test whether there are significant differences exists, the data is further subjected to Analysis of variance.

Graph 2.1: showing the levels of mental health among adolescent girls studying in various streams.

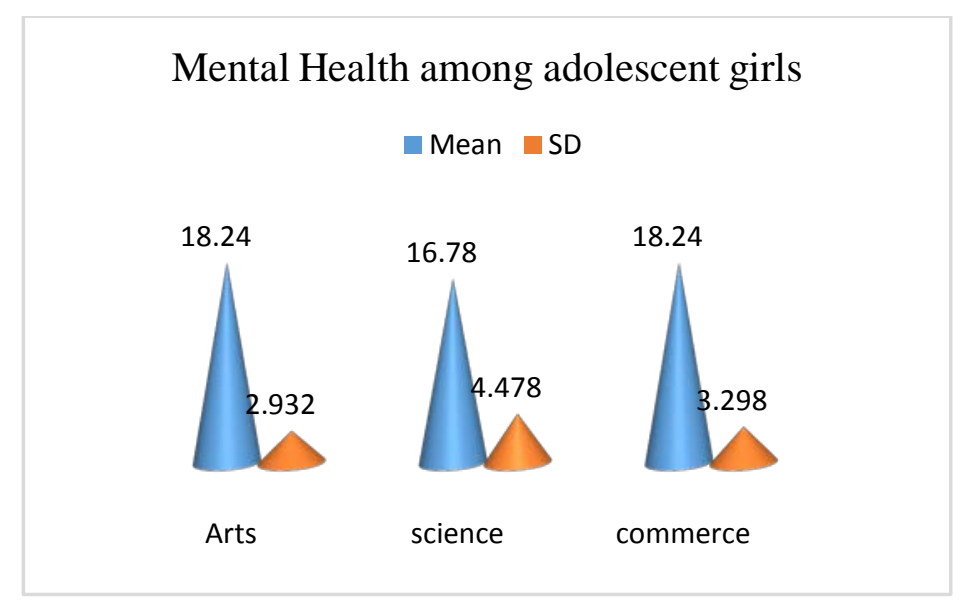

(C) The International Journal of Indian Psychology, ISSN 2348-5396 (e) | ISSN: 2349-3429 (p) | 149 
Table 2.2- Showing significant difference between the level mental health of adolescent girls studying in various streams.

\begin{tabular}{|c|c|c|c|c|c|}
\hline & $\begin{array}{l}\text { Sum of } \\
\text { Squares }\end{array}$ & df & Mean Square & $\mathbf{F}$ & Sig. \\
\hline Between Groups & 71.053 & 2 & 35.527 & \multirow{3}{*}{2.696} & \multirow{3}{*}{.071} \\
\hline Within Groups & 1936.820 & 147 & 13.176 & & \\
\hline Total & 2007.873 & 149 & & & \\
\hline
\end{tabular}

Table no 3 shows that the $\mathrm{F}_{(2,147)}$ value for mental health is 2.696 which is significant as $\mathrm{p}>$ 0.05 ( $p=0.071)$. It shows that there is no significant difference between the level of mental health of adolescent girls studying in various streams. The obtained result does not support stated hypothesis, hence on the basis of result hypothesis is rejected.

Hypotheses 3: There is a positive relationship between mobile phone addiction and mental health of adolescent girls studying in various streams.

Table 3.1: Showing relationship between mobile phone addiction and mental health

\begin{tabular}{|l|l|r|r|}
\hline \multicolumn{1}{|l|}{ Addiction } & \multicolumn{1}{|c|}{ Addiction } & \multicolumn{1}{|c|}{ Mental Health } \\
\hline \multirow{4}{*}{ Mental health } & Pearson Correlation & 1 & $.406^{* *}$ \\
\cline { 2 - 4 } & Sig. (2-tailed) & 150 & .000 \\
\cline { 2 - 4 } & $\mathrm{N}$ & $.406^{* *}$ & 150 \\
\cline { 2 - 4 } & Pearson Correlation & .000 & 1 \\
\cline { 2 - 4 } & Sig. (2-tailed) & 150 & 150 \\
\cline { 2 - 4 } & $\mathrm{N}$ & & \\
\hline \multirow{2}{*}{$* *$ Correlation is significant at the 0.01 level (2-tailed). }
\end{tabular}

Table no 3 shows the correlation between mobile phone addiction \& mental health among adolescent girls studying in various streams. Coefficient of Correlation (r)value is 0.406 which is significant at 0.01 level ( 2 tailed), it indicates positive and significant correlation between mobile phone addiction \& mental health. It predicts that higher the level of mobile phone addiction lower will be the mental health. It can be concluded that addiction of mobile phones effect the mental health of adolescent girls.

\section{FINDINGS AND DISCUSSION}

The research findings reveal that that there is significant difference between the level mobile phone addiction of adolescent girls studying in various streams. No significant difference was found between the level mental health among adolescent girls studying in various streams. Results also depicts that Positive and significant correlation was found between mobile phone addiction \& mental health which predicts that higher the level of mobile phone addiction lower will be the mental health. It is suggested that parent should Monitor their mobile 
activity in friendly way by becoming friend to their daughters. Parents should be ready to help and support them in any situation. Limit must be set on the money that is given out monthly for phone as well as on Internet data. The youth passing through the chaos, disturbance and mental incapacitation. It is recommended that the physical exercise or involving in sports is one of the effective factors in mental health. The Mental wellbeing can be improved by focusing on the fundamentals of the way of living our life.

\section{Acknowledgments}

The author appreciates all those who participated in the study and helped to facilitate the research process.

Conflict of Interests: The author declared no conflict of interests.

\section{REFERENCES}

Best Ways to Fight Teen Cell Phone Addiction. (2016).Pumpic: Mobile monitoring. Retrieved from https://pumpic.com/security/teenage-cell-phone-addiction/

Bhardwaj, Mrunal \& Sode Jaimala Ashok.(2015). Mobile Phone Addiction and Loneliness among Teenagers. The International Journal of Indian Psychology ISSN 2348-5396 (e) ISSN: 2349-3429 (p) Volume 2, Issue 3, Paper ID: B00361V2I32015.retrieved from http://www.ijip.in

Charvi. (2017). A Study Highlights Cell Phone Addiction to Mental Health Problems among Adolescents. She the people. Retrieved from http://www.shethepeople.tv/a-studyhighlights-cell-phone-addiction-to-mental-health-problems-among-adolescents/

Chóliz M.(2012).Mobile-phone addiction in adolescence: The Test of Mobile Phone Dependence (TMD). Progress in Health Sci 2012, Vol 2 , No1.Retrieved from progress.umb.edu.pl/sites/progress.umb.edu.pl/files/33-44\%20Choliz.pdf

Kamalkhurana \& Shwatadikshit. (2016). A comparative study of mobile phone addiction among girls and boys. An International Registered \& Referred Monthly Journal.Retrieved from www. researchlink.co/wp-content/uploads/issues/145/11Psychology.pdf

Purvi Nishad \& Amar Singh Rana.(2016). Impact of mobile phone addiction among college going Students. Advance research journal of social science Volume 7, Issue 1, June, 2016 | 111-115 e ISSN-2231-6418. Retrieved from www.researchjournal.co.in

Sean Coughlan Education correspondent. (2016) Teenage girls: Mental well-being 'worsening'. BBC News. Retrieved from www.bbc.com/news/education-37158441

Vandana Goswami, Dr. Divya Rani Singh. (2016). Impact of mobile phone addiction on adolescent's life: A literature review. International Journal of Home Science 2016; 2(1): 69-74. Retrieved from www.homesciencejournal.com/archives/2016/vol2issue1/PartB/2-1-19.pdf

What is mental health? (n.d). Mentalhealth.gov. Retrieved from, https://www.mentalhealth.gov/basics/what-is-mental-health/

How to cite this article: Patel S A \& Puri P A (2017). A Study of Mobile Phone Addiction and Mental Health among Adolescent Girls Studying in Various Streams International Journal of Indian Psychology, Vol. 5, (1), DIP: 18.01.099/20170501, DOI: 10.25215/0501.099 